\title{
KERJASAMA BILATERAL INDONESIA-MALAYSIA: STUDI TENTANG SOSEK MALINDO DALAM PEMBANGUNANPOS PEMERIKSAAN LINTAS BATAS DI JAGOI BABANGKABUPATEN BENGKAYANG - KALIMANTAN BARAT
}

\author{
Nurfitri Nugrahaningsih \\ Universitas Tanjungpura, email : nurfitri_nn@yahoo.com
}

\begin{abstract}
ABSTRAK Penelitian ini difokuskan pada peran Organisasi Bilateral Indonesia-Malaysia dalam pembangunan perbatasan dengan mengeksplorasi persoalan-persoalan yang dihadapi oleh Tim Teknis Sosek-Malindo (Organisasi Bilateral Indonesia -Malaysia khususnya dalam isu sosial ekonomi).Organisasi ini sudah berdiri sejak tahun 1985, namun belum dapat berperan secara optimal dalam pembukaan Pos Pemeriksaan Lintas Batas Jagoi Babang di Kabupaten Bengkayang.Penelitian ini menggunakan Metode Kualitatif, dengan teknik pengumpulan data melalui wawancara dan observasi.Untuk menganalisis data, peneliti mengambil beberapa langkah dimulai dari mengorganisir data mentah sampai dengan menginterpretasikan arti dari ide pokok dan keterangannya. Untuk menguji keabsahan data peneliti menggunakan stategi validitas yang salah satunya adalah triangulasi sumber data yang berbeda. Berdasarkan berbagai sumber data, peneliti menemukan beberapa faktor seperti : (1) Keberadaan Pos Pemeriksaan Lintas Batas Jagoi Babang belum menjadi prioritas bagi Malaysia karena belum menguntungkan secara sosial ekonomi. (2) Diplomasi yang dilakukan belum optimal. (3) Kurangnya komitmen pemerintah terhadap pembangunan PPLB Jagoi Babang (4) Adanya Outstanding Boundary Problem(OBP). Penelitian ini menyimpulkan, khususnya dalam pembangunan Pos Pemeriksaan Lintas Batas Jagoi Babang, pemerintah harus lebih pro aktif dalam menyelesaikan persoalan Outstanding Boundary Problem, berkomitmen dalam mengikuti forum-forum Sosek Malindo, dan mengoptimalkan diplomasi sehingga keberadaan Pos Pemeriksaaan Lintas Batas di Jagoi Babang juga dapat menjadi prioritas bagi Malaysia. Penelitian Disertasi ini mengajukan konsep untuk memperkuat kerjasama bilateral dalam Sosek Malindo melalui “ wider participation” yang melibatkan NGO's dan civil society sebagai aktor-aktor penting selain pemerintah.
\end{abstract}

Kata Kunci : Pos Pemeriksaan Lintas Batas, Kerjasama Bilateral, Diplomasi, Outstanding Boundary Problem.

$$
\begin{gathered}
\text { INDONESIA - MALAYSIA'S BILATERAL COOPERATION: } \\
\text { A STUDY ON SOSEK MALINDO IN THE BORDER CROSSING CHECKPOINT } \\
\text { DEVELOPMENT IN JAGOI BABANG BENGKAYANG REGENCY - WEST KALIMANTAN }
\end{gathered}
$$

\begin{abstract}
The research is focused on the role of bilateral organization of Indonesia-Malaysia in border development and explores the challenges faced by the technical team of Sosek Malindo (bilateral organization of Indonesia - Malaysia specializes in Social Economic issues). This organization was founded in 1985 yet they haven't been able to provide an optimum contribution in development The Border Crossing Checkpoint in Jagoi Babang, Bengkayang Regency. This research employed qualitative research method. In collecting data, theresearcher has used in-depth interview and observation. To analyze data researcher used some steps from organized and prepared raw data until interpretated the meaning of themes and descriptions. To test the validity of research, the researcher utilized validiy strategies, which one of them is triangulated different data sources of information. Based on various sources of data, the researcher found some factors such as: (1)The existence of The Border Crossing Checkpoint in Jagoi Babang is not yet a priority for Malaysia, because there is not yet social and economic's benefit (2)Insufficient of diplomacy(3)Lackof government's commitment in border development of Jagoi Babang. (4) The Oustanding Boundary Problem (OBP) in Jagoi Babang. The research suggested, particulary in development of The Border Crossing Checkpoint in Jagoi Babang, the government needs to be more pro-active in solving the Oustanding Boundary Problem, commitment in following the Sosek Malindo forums, and in optimizing diplomacy to make the existence of The Border Crossing Checkpoint in Jagoi Babang should become a priority for Malaysia as well. This dissertation's research proposed concept to strengthen bilateral cooperation in Sosek Malindo through 'wider participation' which involved NGO's and civil society as important actors besides the government.
\end{abstract}

Key Words : Border Crossing Checkpoint, Bilateral Cooperation, Diplomacy, Outstanding Boundary Problem.

\section{PENDAHULUAN}

Propinsi Kalimantan Barat dengan luas wilayah 146.807 $\mathrm{km} 2$ atau setara dengan 1 1/2 kali pulau Jawa, merupakan propinsi yang berbatasan langsung dengan Serawak (Malaysia Timur) di 5 (lima) Kabupaten, yakni Kabupaten Sanggau, Sambas, Bengkayang, Sintang, dan Kapuas Hulu. Wilayah perbatasan ini membentang sepanjang $966 \mathrm{~km}$ yang melintasi 40 desa dalam 15 kecamatan. Luas wilayah perbatasan Kalbar lebih kurang 2,42 juta ha, dan kepadatan penduduk rata-rata 8 jiwa/km2.
Kalimantan Barat saat ini barumemiliki2(dua) PPLB (Pos pemeriksaan Lintas Batas) yaitu di Entikong Kabupaten Sanggau yang memiliki fasilitas CIQS (Custom, Immigration, Quarantee and Security) lengkap dan beroperasi dengan normal, sedangkan PPLB di Aruk Kabupaten Sambas yang diresmikan pada tanggal 1 Januari 2011belum dapat beroperasi secara optimal karena belum lengkapnya fasilitas penunjang CIQS yang dimiliki. Adapun keberadaan PLB di Badau Kabupaten Kapuas Hulu 
yang telah soft lauchinguntuk ditingkatkan statusnya sebagai PPLB pada tanggal 20 Oktober 2012, juga belum dapat beroperasi secara optimal karena masih menunggu ijin dari pemerintah pusat, sehingga statusnya masih tetap PLB.

Pos Lintas Batas diperlukan bagi pengaturan lalu lintas perdagangan dan interaksi antar warga negara. Sesuai perkembangan dan tuntutan zaman, peningkatan status PLB menjadi PPLB atau TPI (Tempat Pemeriksaan Imigrasi) sangat diperlukan. Pemerintah berencana membukaborder gate di wilayah Jagoi Babang Kabupaten Bengkayang dari status PLB menjadi PPLB untuk membuka isolasi daerah, meningkatkan akses ke luar negeri dan mendorong perkembangan perekonomian daerah, juga sebagai salah satu alternatif kebijakan pengembangan pembangunan kawasan perbatasan.

Persoalan di perbatasan Jagoi Babang Kabupaten Bengkayang cukup banyak. Data yang diperoleh dari Polda Kalbar dalam salah satu seminar mengenai perbatasan (2011) menyebutkan beberapa persoalan spesifik di wilayah perbatasan Jagoi Babang yakni : (1). Permasalahan Gula, seperti Polisi Lintas Batas \& TDM (Tentara Diraja Malaysia) sering membiarkan tukang ojek membawa masuk gula satu / dua sak dari Serikin Malaysia ke Jagoi Babang dengan cara masuk ke Serikin tanpa Pas Lintas Batas, hanya meninggalkan Kartu Tanda Penduduk (KTP) di Pos TDM. (2). Permasalahan kayu, yaitu kayu tangkapan/temuan di perbatasan tidak dijaga, sehingga sering diambil oleh Malaysia dengan pengawalan TDM. (3). Permasalahan di Desa Semunying Jaya, yaitu penggeseran patok batas Negara, mengambil lahan sawit di wilayah Indonesia, mengambil kayu dan memasukkan alat berat dikawal oleh TDM, dengan mengklaim bahwa itu wilayah Malaysia, juga terdapat permasalahan penyelundupan mobil dari Serikin ke Bengkayang.

Persoalan di atas menggambarkan arti penting keberadaan Pos Pemeriksaan Lintas Batas (PPLB) di Kecamatan Jagoi Babang Kabupaten Bengkayang Risalah Sidang ke $23 \mathrm{KK} / \mathrm{JKK}$ Sosek Malindo Tingkat /Peringkat Daerah Kalbar-Negeri Serawak di Pontianak tanggal 3-4 Agustus 2007 menyebutkan bahwa rencana pembukaan PPLB Jagoi Babang adalah salah satu agenda yang dibahas. Pihak Malaysia juga sudah menyetujui pembangunan gedung CIQS di lintas batas Jagoi Babang-Serikin awal tahun 2008. Namun ketika sidang itu belum berlangsung, ternyata Indonesia sudah lebih dahulu membangun gedung tersebut. Gedung CIQS di Kecamatan Jagoi Babang sudah diresmikan oleh Gubernur Kalimantan Barat Usman Jaffar pada bulan April 2007, akan tetapi hingga saat ini, fasilitas tersebut belum juga dioperasionalkan. Bahkan pihak Malaysia juga belum membangun fasilitas CIQS nya di Serikin.

Walaupun persoalan perbatasan begitu kompleks, pada tataran pemerintah hubungan kerjasama Indonesia-Malaysia cukup harmonis. Hubungan kerjasama kedua Negara dibingkai oleh kerjasama regional/bilateral dalam Assosiation Of South East Asian Nations (ASEAN), Brunei DarussalamIndonesia-Malaysia-The Philippines- East ASEAN Growth Area (BIMP-EAGA), Indonesia-MalaysiaSingapore Growth Triangle(IMS-GT) dan Sosial Ekonomi Malaysia-Indonesia(Sosek Malindo).

Sosek Malindo merupakan organisasi bilateral dalam pembangunan sosial ekonomi antara Indonesia Malaysia yang berdiri sejak tahun 1985. Pedoman Pokok Organisasi Sosek Malindo menyebutkan bahwa organisasi ini bertujuan meningkatkan taraf hidup masyarakat di wilayah perbatasan. Usaha tersebut tidak terlepas dengan usaha pembinaan kesiapan dan kewajiban bernegara mayarakatnya agar mampu berpartisipasi penuh untuk mencapai tujuan stabilitas wilayah perbatasan.Tugas pokok Kelompok Kerja Sosial Ekonomi Malaysia Indonesia (KK Sosek - Malindo) atau yang di Malaysia disebut Jawatan Kuasa Kerja (JKK) Sosek Malindo adalah membuat kajian terhadap proyek-proyek bersama pada kawasan perbatasan untuk kesejahteraan masyarakat di kedua negara.Namun pada kenyataannya, Tim Teknis Bidang Pembangunan Pos Pemeriksaan Lintas Batas (PPLB) Tingkat Daerah Kalbar, belum berhasil dalam upaya pembukaan PPLB di Jagoi Babang Kabupaten Bengkayang.

Banyak penelitian-penelitian mengenai perbatasan Indonesia-Malaysia selama ini. misalnya : Herawati(2009) yang menitikberatkan pada peran serta masyarakat dalam pembangunan perbatasan, Effendy, dkk (2009) tentang kewenangan Pemerintah Daerah dalam pengelolaan kawasan perbatasan di era Otonomi Daerah, Paton(2005) yang mengedepankan pada peran pemimpin informal dalam pembangunan perbatasan, Tangdililing, $\operatorname{dkk}(2011)$ mengenai kesiapan masyarakat Jagoi Babang- Siding dalam rangka pembukaan border gate di Kabupaten Bengkayang, Suratman(2008) yang mengangkat persoalan kawasan perbatasan dan pembangunan daerah dengan pendekatan sistem neraca sosial ekonomi, juga ada yang membahas mengenai hubungan Indonesia-Malaysia dalam bidang ekomoni (Saherimiko:2002, Surahman:2008). Penelitian mengenai Penataan Gate Jagoi Babang juga telah pernah dilakukan oleh Tim peneliti Untan(2006) . Akan tetapi, penelitian-penelitian tersebut belum menyentuh pada persoalan peran lembaga /organisasi bilateral Indonesia-Malaysia dalam pembangunan perbatasan. Penelitian ini berusaha menjawab kekosongan penelitian mengenai peran organisasi kerjasama bilateral dalam pembangunan perbatasan.

Permasalahan dalam penelitian ini adalah: Mengapa keberadaan Tim Teknis Sosek Malindo Bidang Pembangunan Pos Pemeriksaan Lintas Batas (PPLB) Tingkat Daerah Kalbar belum berperan secara 
optimal dalam pembukaaan Pos Pemeriksaan Lintas Batas (PPLB) di Kecamatan Jagoi Babang Kabupaten Bengkayang? Untuk mengkaji permasalahan tersebut penelitian ini membangun kerangka pemikiran yang mengacu pada konsep Kerjasama Internasional.

Dalam studi Hubungan Internasional, konsep Kerjasama Internasional mengalami perubahan dan perkembangan didasari pada Sistem Internasional yang selalu dinamis. Dua paradigma utama dalam Hubungan Internasional yaitu Pluralis/Liberalis dan Realis mempunyai perspektif yang berbeda terutama dalam melihat aktor dominan yang berperan dalam kerjasama internasional.Peneliti menggunakan konsepsi aktor sebagai titik tolak untuk membedakan kedua paradigma besar ini.

Paradigma Realis yang menganggap negara adalah aktor utama dan terpenting dalam Kerjasama Internasional, dan menganggap negara adalah aktor yang rasional ternyata belum mampu menjawab tantangan perubahan. Negara, yang memiliki kekuasaan dan kekuatan tentunya akan berupanya untuk status quo, dalam arti ingin terus melanggengkan kekuasaannya, mempertahankan kontrol dan pengaruhnya. Hal tersebut membuat paradigma Realis dianggap terlalu terobsesi oleh negara, kurang imaginasi dan belum mampu menawarkan alternatif-alternatif lain menghadapi perubahan Sistem Internasional.

Kemunculan Paradigma Pluralis/Liberalis dengan pemikiran bahwa negara yang terdiri atas individuindividu dengan beragam kepentingan, belum tentu dapat menghasilkan kebijakan-kebijakan yang rasional. Sehingga Paradigma Pluralis menawarkan alternatif perubahan dengan menganggap pentingnya keterlibatan aktor non negara, karena tidak mungkin memahami Kerjasama Internasional tanpa mempertimbangkan beragamnya aktor internasional dan kompleksitas isu dewasa ini. Paradigma Pluralis/Liberalis ini sangat sesuai untuk menjawab permasalahan dalam penelitian ini.

Sebagai salah satu bentuk dari Kerjasama Internasional, Kerjasama Bilateral yang hanya melibatkan dua negara juga memiliki pertimbangan yang sama. Jika diletakkan dalam kerangka Kerjasama Bilateral, maka Kerjasama Bilateral yang dilakukan oleh Tim Teknis Kelompok Kerja/ KK Sosek Malindo Bidang Pembangunan PPLB Kalbar dengan Tim Teknis Jawatan Kuasa Kerja/ JKK Malaysia dapat dikategorikan sebagai praktek paradiplomacy, yakni diplomasi yang dilakukan oleh Non Central Government atau pemerintah lokal.

Paradiplomacy membutuhkan adanya prioritas bersama untuk mencapai tujuan-tujuan tertentu. Jika pihak pertama mengganggap sebuah isu sebagai prioritas, sedangkan pihak kedua tidak menganggapnya sebagai prioritas, maka keinginan pihak pertama sulit untuk terwujud. Keinginan sepihak dari Tim Teknis Sosek Malindo Kalbar untuk membuka PPLB di Jagoi Babang yang ditunjukkan dengan berbagai upaya Pemerintah Daerah Kalbar melakukan pembangunan di sekitar Pos Lintas Batas Jagoi Babang ternyata belum membuahkan hasil. Pihak Malaysia belum melakukan pembangunan apapun di wilayahnya yang menunjukkan hal tersebut belum menjadi isu prioritas bagi Malaysia.

Faktor yang lain adalah diplomasi yang dilakukan selama ini masih bersifat tertutup, sukar diakses oleh publik dan belum melibatkan aktor lain selain pemerintah. Padahal dalam Kerjasama Bilateral diperlukan partisipasi yang lebih luas dari masyarakat untuk dapat ikut terlibat dalam diplomasi. Aktoraktor yang lebih luas akan dapat menawarkan alternatif pemecahan masalah dengan solusi yang lebih beragam dalam rapat-rapat maupun sidangsidang Sosek Malindo. Selama ini diplomasi yang dilakukan belum melibatkan peran masyarakat, padahal tuntutan akan partisipasi yang lebih luas dari masyarakat sejalan dengan nilai nilai dan prinsipprinsip demokrasi.

Komitmen pemerintah juga merupakan faktor yang sangat menentukan.Masalah utama pembangunan perbatasan adalah kurangnya perhatian pemerintah pada kawasan tersebut. Kondisi yang tampak di kawasan perbatasan selama ini yang masih tertinggal, terbelakang, dengan tingkat kesejahteraan dan pendidikan yang rendah, akses yang sukar dan kemiskinan yang tinggi menunjukkan bahwa keinginan pemerintah untuk menjadikan kawasan perbatasan sebagai beranda depan dapat dikatakan baru sebatas wacana. Peneliti melihat adanya kecendrungan bahwa Kalbar juga mengalami masalah yang sama, jika kita lihat dari banyaknya persoalan perbatasan yang belum bisa diselesaikan oleh pemerintah, hal tersebut menunjukkan kurangnya komitmen pemerintah dalam pengelolaan perbatasan.

Kerangka pemikiran di atas mengantarkan peneliti pada suatupreposisi bahwa faktor yang menyebabkan keberadaan Tim Teknis Sosek Malindo Bidang Pembangunan Pos Pemeriksaan Lintas Batas (PPLB) Kalbar belum berperan secara optimal dalam pembukaaan Pos Pemeriksaan Lintas Batas (PPLB) di Kecamatan Jagoi Babang Kabupaten Bengkayang dikarenakan: (a)isu yang diangkat belum merupakan prioritas bagi Malaysia,(b)adanya persoalan dalam Diplomasi, dan (c) kurangnya komitmen pemerintah.

\section{METODE}

Jenis penelitian ini termasuk eksploratif dengan metode kualitatif. Penelitian kualitatif adalah proses penyelidikan dimana peneliti mencoba untuk membangun gambaran yang holistik terhadap masalah-masalah atau isu yang diamati, sehingga diperlukan perspektif yang beragam, dan perlu mengidentifikasi faktor-faktor yang terlibat dalam situasi tertentu. Sumber data/ informan dalam 
penelitian ini ditentukan secara purposive, dengan kriteria sebagai berikut: (1) Pihak-pihak yang terkait dalam kerjasama bilateral Sosek Malindo (2) Tim Teknis Bidang Pembangunan Pos Pemeriksaan Lintas Batas (baik itu pihak Indonesia maupun pihak Malaysia). (3) Pihak-pihak yang terkait dengan aktifitas lintas batas di Kecamatan Jagoi-BabangSerikin (4) Sejumlah informan yang dianggap kompeten, pernah melakukan penelitian sebelumnya berkaitan dengan masalah yang diteliti, atau banyak mengetahui tentang hal yang diteliti.

Instrumen atau alat utama yang dipergunakan dalam penelitian ini adalah peneliti sendiri (Creswell, 2009: 175). Selain itu, alat pengumpulan data yang lain disesuaikan dengan tehnik pengumpulan data yang digunakan, yaitu: (1). Wawancara mendalam, alat yang digunakan adalah pedoman wawancara, buku catatan, pena, digitalvoice recorder, dan kamera(2). Observasi lapangan, alat yang digunakan adalah pedoman observasi, buku catatan dan pena. (3). Pemeriksaan dan pengumpulan dokumen, alat yang digunakan buku catatan, komputer, flash disk, pena dan mesin photocopy untuk menggandakan dokumen.

Analisis data dalam penelitian ini dilakukan dengan beberapa langkah yakni (1).Organizing and Preparing,melakukan persiapan untuk analisis data, termasuk melakukan transkripsi dari hasil wawancara yang direkam.(2).Reading Through All Data, peneliti membaca keseluruhan data untuk menemukan general ideas dan general thought dari informan, (3).Coding the Data, peneliti menandai data-data yang penting, data yang unik dan data yang tidak terantisipasi sebelumnya, kemudian membuat daftar dan kategori data-data sifatnya hampir sama. (4) Themes-Description. Dari data -data yang sudah ditandai, peneliti melakukan pemilahan apakah data tersebut merupakan ide pokok atau keterangan. (5). Interrelating Themes/Description.Yakni menghubungkan ide-ide pokok dan keterangannya. (6). Interpreting the meaning of themes and description, keseluruhan data yang diperoleh diinterpretasikan oleh peneliti untuk menemukan kesimpulan.

Teknik pemeriksaan keabsahan data/validitas data dilakukan Peneliti dengan validity strategiesyang diadopsidariCresswell (2009) dalam upaya untuk memperoleh data yang benar- benar valid, dengan beberapa cara (1). Triangulate different data source of information, dengan Triangulasi, hasil penelitian yang berasal dari banyak sumber (several sources) lebih valid. (2). Use rich, thick description to convey the findings, peneliti berupaya memberikan gambaran detail, untuk hasil penelitian yang lebih baik. (3). Also present negative or discrepant information, juga dikemukakan temuan-temuan/ informasi yang sifatnya negatif, maupun kontradiktif, sehingga hasil penelitian lebih realistis dan valid. (4)
Spent prolonged time in the field, semakin banyak pengalaman di lapangan, semakin akurat dan valid temuan yang diperoleh.(5). Use peer debriefing (menggunakan teman untuk melakukan wawancara) sehingga mendapatkan data yang lebih banyak. (6). Use an external auditor to review, dengan menggunakan external auditor to review dapat memberikan penilaian objektif terhadap hasil studi. Dalam penelitian ini, peneliti menggunakan rekan yang memahami dan berpengalaman dalam metode penelitian dan ahli yang berpengalaman dalam Sosek Malindo sebagai auditor.

\section{HASIL DAN PEMBAHASAN}

Hasil wawancara dan pengamatan memperlihatkan dengan jelas bahwa Malaysia belum menganggap keberadaan Pos Pemeriksaan Lintas Batas Jagoi Babang sebagai isu prioritas karena belum menguntungkan secara sosial-ekonomis. Hal tersebut didukung oleh fakta-fakta berikut ini :(1). Minimnya warga Malaysia yang menggunakan Pos Lintas Batas (PLB) Jagoi Babang dalam 3 tahun terakhir, yang dibuktikan dengan kondisi yang menunjukkan rendahnya arus keluar masuk warga Malaysia yang melewati Pos Lintas Batas di Jagoi Babang-Serikin (2) Keberadaan Pasar Serikin yang menguntungkan Malaysia, data-data hasil wawancara menunjukkan hal tersebut. Demikian pula notulen-notulen rapat, termasuk Minit Mensyuarat (catatan sidang) dari pihak Tim Teknik Kerjasama Pembangunan Pos Imigresen Kawasan Sempadan Sosek Malindo Peringkat Negeri Serawak yang menunjukkan bahwa dalam pembicaraan mengenai Pos Jagoi Babang-Serikin pihak Malaysia mempertimbangkan keberadaan Pasar Serikin, (3)Kondisi jalan dari Jagoi-Babang ke Serikin (memasuki wilayah Malaysia) yang masih belum dibangun. Ini menunjukkan Malaysia belum melakukan pembangunan infrastuktur untuk menunjang keberadaan PPLB. (4) Hasil wawancara dengan Ketua Tim Delegasi Malaysia bahwa Malaysia untuk saat ini memprioritaskan keberadaan PPLB di Aruk-Biawak. Dari hasil wawancara dan notulennotulen sidang menunjukkan bahwa Malaysia saat ini belum memprioritaskan PPLB Jagoi Babang-Serikin.

Diplomasi juga menjadi salah salah satu faktor penyebab, para anggota Sosek Malindo Tingkat Daerah Kalbar adalah pejabat di dinas-dinas tertentu, yang bertindak sebagai pelaku diplomasi namun belum memiliki kemampuan dalam diplomasi dan kemahiran dalam negosiasi. Adanya pergantian anggota Sosek Malindo secara terus menerus karena jabatan birokratis yang diembannya tentunya perlu mendapatkan perhatian karena hal tersebut menyebabkan kurangnya informasi, pengalaman dan pengetahuan dari anggota. Padahal isu-isu yang bergulir dan dibicarakan membutuhkan keahlian dan pengetahuan yang luas dalam memahami setiap isu.Kerjasama Bilateral Sosek Malindo saat ini 
belum melibatkan pihak-pihak di luar pemerintah (masyarakat), padahal keterlibatan pihak ketiga ini sesuai dengan konsep open diplomacydan new diplomacy yang memang memberikan ruang yang luas kepada pihak-pihak ketiga untuk ikut terlibat dalam berdiplomasi.

Komitmen Pemerintah juga menjadi salah satu faktor penyebab, dimana pada kenyataannya baik pemerintah pusat maupun pemerintah daerah belum mampu menjalankan perannya dengan baik sesuai dengan apa yang diharapkan oleh masyarakat terhadap posisi dan kedudukan mereka sebagai pemerintah. Sebagaimana yang dikatakan oleh salah seorang pengamat perbatasan Kalbar yakni adanya inkonsistensi antara pelaksanaan dan kebijakan. Konsep-konsep yang dibuat oleh pemerintah sudah cukup baik, namun dalam tataran pelaksanaannya masih jauh dari harapan.Peneliti menilai, komitmen pemerintah masih rendah dalam pembangunan PPLB di Jagoi Babang, perbatasan sering dijadikan komoditas politik, tanpa adanya upaya upaya yang konkret untuk mewujudkan pembangunan dan kesejahteraan masyarakat di perbatasan. Jika pemerintah berkomitmen dalam membangun PPLB Jagoi Babang, maka yang harus dilakukan terlebih dahulu oleh pemerintah adalah menentukan titik O(nol), bukan melakukan pembangunan gedung CIQS seperti yang dilakukan saat ini. Pembangunan yang dilakukan dapat peneliti katakan sebagai pembangunan yang belum tepat karena persoalan yang mendasar belum diselesaikan. Jika Porter et al. (1974:603) menerangkan komitmen organisasi yakni memiliki kepercayaan yang kuat dan penerimaan terhadap tujuan-tujuan organisasi dan keinginan untuk exert considerable effort atas nama organisasi, maka dapat dikatakan bahwa komitmen pemerintah dalam hal ini masih rendah. Untuk mewujudkan tujuan organisasi para anggotanya perlu melakukan tugas-tugas organisasi /mengerahkan upaya-upaya yang diperlukan untuk tujuan organisasi.

Alasanlain yang menyebabkan Tim Teknis Sosek Malindo belum dapat merealisasikan pembangunan PPLB di Jagoi Babang adalah karena adanya persoalan OBP (Outstanding Boundary Problems) di Jagoi Babang. Persoalan OBP termasuk dalam persoalan penetapan garis batas yang menyebabkan penentuan titik 0 (nol) belum bisa dilakukan sehingga pembangunan PPLB menjadi jalan di tempat. Upaya yang dilakukan pemerintah Indonesia dan Malaysia saat ini dalam penentuan calon titik 0 sudah dilakukan walaupun sampai tahun 2012 lokasi calon titik 0 tersebut belum tetapkan oleh kedua Negara. Pemerintah Indonesia saat ini sudah memulai pembangunan PPLB dengan membuat pondasi gedung PPLB dan jalan perbatasan. Walaupun demikian pembangunanPos Lintas Batas yang telah mulai dilakukan itu tidak akan dapat meningkat statusnya menjadi Pos Pemeriksaan Lintas Batas sebelum
Pemerintah Indonesia dan Malaysia bersepakat untuk menyelesaikan persoalan OBP di Jagoi Babang. Penyelesaian masalah OBP yakni kesepakatan dalam persoalan titik-titik batas negara dan penetapan zero point di Jagoi Babang menjadi suatu hal penting yang harus segera dilakukan pemerintah.

\section{SIMPULAN}

Berdasarkan hasil penelitian, dapat ditarik kesimpulan :Pertama, Keberadaan PPLB di Jagoi Babang belum merupakan mutual priority antar Pemerintah Indonesia dan Malaysia. Indonesia menganggap PPLB Jagoi Babang sebagai prioritas dilihat dari tingginya mobilitas warga Indonesia yang menggunakan PLB dan pembangunan-pembangunan yang sudah dilakukan. Malaysia belum menjadikan PPLB Jagoi Babang sebagai prioritas karena belum menguntungkan secara sosial ekonomi. Keberadaan pasar Serikin yang saat ini menguntungkan Malaysia secara ekonomis membuat pemerintah Malaysia lebih memprioritaskan border Aruk di Kabupaten Sambas yang berbatasan dengan Biawak(Malaysia). Selain itu masyarakat perbatasan di wilayah Jagoi Babang juga belum mengganggap PPLB sebagai prioritas.

Kedua,Kelemahandiplomasi karena aktor pelaksanadiplomasi dalam kerjasama Sosek Malindo adalah birokrat yang posisinya sering berganti. Birokrat yang sering berganti tersebut membuat personil yang terlibat kurang menguasai isu-isu yang dibahas dalam sidang-sidang.Diplomasi yang dilakukan selama ini juga belum melibatkan partisipasi yang luas dari aktor pelaksananya.

Ketiga, Kurangnya komitmen pemerintah, yang terlihat dari (a) Komitmen pemerintah dalam pembangunan PPLB. Dalam sejarahnya, PLB Jagoi Babang adalah PLB yang pertama di Indonesia, Pemerintah sejak rejim Orde Baru sampai dengan sekarang sudah mengetahui kendala PLB Jagoi Babang tidak dapat dinaikkan statusnya menjadi PLBB karena ada persoalan garis batas. Namun hal tersebut tidak pernah ditindak lanjuti oleh pemerintah. Hal yang dilakukan oleh pemerintah adalah melakukan pembangunan di PLB Jagoi Babang seperti pembangunan Pos terpadu dan pembangunan pondasi PPLB yang dilakukan saat ini, namun hal tersebut menjadi sia-sia sebelum pemerintah menyelesaikan persoalan garis batas di Jagoi Babang. (b) Kurangnya komitmen pemerintah dalam Sosek Malindo. Pada point ini, peneliti berargumen bahwa kurangnya keaktifan anggota Tim Teknis Sosek Malindo dalam organisasi Sosek Malindo, dan banyaknya anggota Tim Teknis Sosek Malindo yang tidak mengikuti rapat-rapat dan sidang Sosek Malindo memperlihatkan kurangnya komitmen pemerintah.

Keempat, Outstanding Boundary Problems(OBP) di Jagoi Babang.Problem garis batas di Jagoi Babang yang belum diselesaikan oleh Indonesia-Malaysia 
menyebabkan sampai saat ini Pos Lintas Batas Jagoi

Babang belum dapat ditingkatkan statusnya menjadi

Pos Pemeriksaan Lintas Batas.

\section{DAFTAR PUSTAKA}

Creswell, John W. 2009. Research Design: Qualitative, Quantitative and Mixed Methods Approaches. USA: Sage Publications Ltd.

Departemen Luar Negeri RI, 1999. ASEAN Selayang Pandang . Jakarta: Dirjen Kerjasama ASEAN

Suharsono, "Perkembangan Politik Luar Negeri Indonesia" .Jurnal Luar Negeri No 41, 2000.

Badan Koordinasi Survey dan Pemetaan Nasional. 2007. Atlas Wilayah Perbatasan Kalimantan Barat

BPS Kabupaten Bengkayang, Kabupaten Bengkayang Dalam Angka 2010

BPS Kab. Bengkayang, Statistik Daerah Kabupaten Bengkayang, 2010.

UU No 43 Tahun 2008 Tentang Wilayah Negara.

UU No 6 Tahun 2001 Tentang Keimigrasian

Majelis Keselamatan Negara, Jabatan Perdana Menteri Malaysia dan Kementrian Dalam Negeri RI, 2011. Buku 25 Tahun Kerjasama KK/JKK Sosek Malindo.
Pedoman Pokok Organisasi Kelompok Kerja Sosial Ekonomi (KK Sosek) Malindo Tingkat Daerah Kalbar- Negeri Sarawak

Risalah-Risalah Sidang Sosek Malindo.Tingkat / Peringkat Daerah Kalbar-Negeri Serawak.

Patton, Adri.2005. Peran Pemimpin Informal Dalam PelaksanaanPembangunan Desa Di Daerah Perbatasan Kabupaten Malinau Kalimantan Timur (Disertasi).Program Pasca Sarjana Universitas Brawijaya Malang.

Effendy, Suratman, Nugrahaningsih, dkk, 2009. Laporan Penelitian Tentang Kewenangan Pemerintah Daerah Dalam Pengelolaan Kawasan Perbatasan Di Era Otonomi Daerah: Studi Kasus Di Kalimantan Barat. Kerjasama Dewan Perwakilan Rakyat Daerah (DPD) RI dan Universitas Tanjungpura

Porter,Lyman W.; Steers.; Richard M.; Mowday,Richard T.; Boulian, \& Paul V. 1974. Organization Commitment, Job satification, and turnover among psychiatric technicians, Journal of Applied Psychology, Vol 59(5): 603-609.

Netty Herawati 2009. Pemberdayaan masyarakat untuk pengembangan pembangunan di wilayah perbatasan dalam rangka mendukung ketahanan Nasional laporan Penelitian kementrian Negara Riset dan Teknologi tahun 2009. 